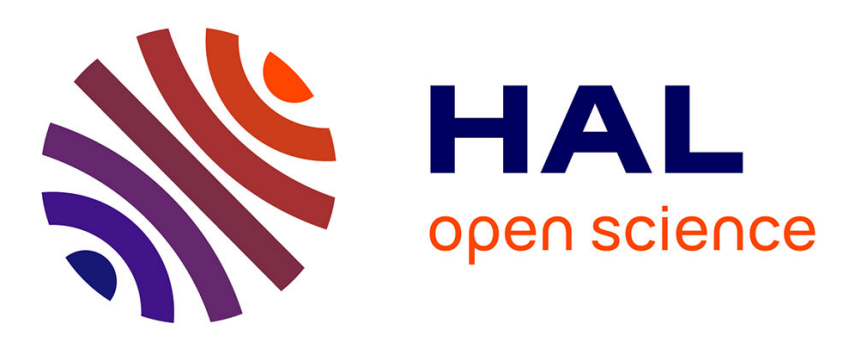

\title{
The historical relation between clause-final negation markers and phasal polarity expressions in Sub-Saharan Africa
}

Dmitry Idiatov

\section{- To cite this version:}

Dmitry Idiatov. The historical relation between clause-final negation markers and phasal polarity expressions in Sub-Saharan Africa. The Expression of Phasal Polarity in African Languages, De Gruyter Mouton, pp.497-514, 2021, 10.1515/9783110646290-020 . halshs-03164118

\section{HAL Id: halshs-03164118 \\ https://shs.hal.science/halshs-03164118}

Submitted on 9 Mar 2021

HAL is a multi-disciplinary open access archive for the deposit and dissemination of scientific research documents, whether they are published or not. The documents may come from teaching and research institutions in France or abroad, or from public or private research centers.
L'archive ouverte pluridisciplinaire HAL, est destinée au dépôt et à la diffusion de documents scientifiques de niveau recherche, publiés ou non, émanant des établissements d'enseignement et de recherche français ou étrangers, des laboratoires publics ou privés. 
The historical relation between clause-final negation markers and phasal polarity expressions in Sub-Saharan Africa

Dmitry Idiatov

LLACAN (CNRS - USPC/INALCO)

e-mail: dmitry.idiatov@cnrs.fr

Dmitry Idiatov

LLACAN - UMR 8135 du CNRS

7, rue Guy Môquet - BP 8

94801 Villejuif Cedex

France 


\begin{abstract}
Clause-final negation markers (CFNMs), although typologically rare, can be found in a very wide range of languages of Sub-Saharan Africa. Given that CFNMs tend to occupy the same constructional slot as phasal polarity expressions (PPEs) and that strong semantic and often also formal links are known to exist between PPEs and negation, default CFNMs may be expected to often develop out of PPEs. However, this expectation is not borne out by the data available on the development of default CFNMs in the languages of Sub-Saharan Africa. The paper discusses a number of cases from Mande languages where CFNMs may be argued to be historically related to PPEs. In line with the general rarity of the change from a PPE to a default CFNM, when evolving into negation markers PPEs tend to maintain the phasal element of their semantics or become restricted to certain TAM constructions. In those rare cases where PPEs may be argued to have evolved into default CFNMs, this evolution is not direct and necessarily proceeds through the addition (or foregrounding) of a free-choice indefinite semantic component (such as 'not yet' $>$ 'not ever yet, not on any occasion yet') and the development of the implicature of an intersubjective operator processing hearer-sided expectations and presuppositions (such as 'not ever yet, not on any occasion yet' > 'not at all, really not').
\end{abstract}

Keywords: African languages, clause-final negation, historical linguistics, intersubjectivity, Jespersen cycle, Mande languages, negative polarity items, phasal polarity expressions, right periphery, semantic change, syntax 


\section{The historical relation between clause-final negation markers and phasal polarity expressions in Sub-Saharan Africa}

\section{Introduction ${ }^{1}$}

Clause-final negation markers (CFNMs) are elements that may be used in the right periphery of negative verbal predications with clause scope negation but that do not appear in the corresponding positive predications and whose position is determined with respect to the clause as a whole. ${ }^{2}$ A clear example of a CFNM is provided by the Gbaya Kara [gya] $]^{3}$ marker ná in (1) which is the sole marker of negation placed at the very end of the utterance, also following the subordinate clause which is not negated itself.

Gbaya Kara

(1) Pám gbé sàdî hấ kóò kóm jón ná

1SG kill LIPFV animal so.that wife POSS.1SG eat IIPFV NEG

'I did not kill game to feed my wife (lit.: so that my wife eats)' (Roulon-Doko 2012:5).

As I show in Idiatov (2018), CFNMs form a clear areal pattern within Sub-Saharan Africa and typologically represent the most striking property of negation marking in Sub-Saharan Africa. On a world-wide scale, CFNMs are much more unusual than postverbal negation markers and multiple negation exponence, the other two features of negation marking that have been shown to be common in Sub-Saharan Africa and whose distribution has also been argued to show a certain areal skewing (cf. Beyer 2009, Dryer 2009, Devos \& van der Auwera 2013). As I argued elsewhere (Idiatov 2012a), CFNMs in Sub-Saharan Africa tend to be characterized by a number of peculiarities in their morphosyntax and diachronic development that set them apart from similar markers elsewhere in the world. Some of these differences are more a matter of degree, yet some do seem to be more fundamental. For instance, CFNMs in African languages are often associated with the presence of multiple negation exponence within a clause, most commonly double but sometimes also triple and occasionally quadruple. CFNMs in

\footnotetext{
${ }^{1}$ This work is part of the projects LC2 "Areal phenomena in Northern Sub-Saharan Africa" and GL7 "Reconstruction, genealogy, typology and grammatical description in the world's two biggest phyla: Niger-Congo and Austronesian" of the Labex EFL (program "Investissements d'Avenir" overseen by the French National Research Agency, reference: ANR-10-LABX-0083). I would like to thank Mark Van de Velde for his comments on an earlier version of this paper. Last but not least, I am grateful to the referees and the editor for their comments.

${ }^{2}$ See Idiatov (2018:122-133) for a discussion of various aspects of this definition.

${ }^{3}$ The three-letter codes between square brackets after the name of language are ISO 639-3 language codes.
} 
Africa often happen to be morphosyntactically deficient as compared to more canonical grammatical markers in being optional or lacking in some types of clauses as conditioned by the TAM value of the predicate of the clause, the subordination status of the clause, the associated information structural and speech act type values or the discourse type that the clause belongs to (cf. Idiatov 2015). Diachronically, CFNMs in the area tend to be rather unstable and appear to be relatively easily borrowable (cf. Idiatov 2012b; 2015), unlike negators in other parts of the world but more like discourse markers, focus particles and phasal polarity expressions (cf. Matras 2009).

In Sub-Saharan African languages, phasal polarity expressions (PPEs) tend to occupy the same clause-final constructional slot as CFNMs, the slot they equally tend to share with markers of illocutionary force, epistemic stance and various other intersubjective operators (or "monitoring-and-directing operators" in terms of Matras 2009:99). In a given language, this competition for the slot on the right periphery of a clause may be resolved in different ways (cf. Idiatov 2018:127-129). For instance, in Dzuun [dnn] the clause-final PPE $\eta \bar{e}$ 'yet, still', as in (2), when combined with negation would usually be used without the default CFNM wāa as in (3), in which case $\eta \bar{e}$ functions as a semantically specific CFNM occupying the CFNM slot of the default CFNM $w \bar{a} \bar{a}$. However, the two markers can also be used together, in which case the PPE precedes the CFNM, as in (4) (cf. Idiatov 2015:256). In Bena-Yungur [yun], the clausefinal PPE $k \bar{a} l k \bar{a} l$ ' 'yet, still', as in (5), when combined with negation follows the CFNM ré, as in (6).

\section{Dzuun}

(2) dzín nì̃ kéréū shē, tà kó nì̃ dón nī child REL born.PFV today DEM and REL belly COP

$\bar{e}$ náà jàn $\eta \bar{e}, \quad$ twē̄i ráá wár'là bèé min

REFL mother in yet DEM POSS money.DEF go.IPFV where

'[The tax, as its amount was not settled,] where did the money go of a child that has been born today or of a child that is yet in his mother's belly?' (Solomiac 2007:571)

(3) kàbī mún kéréū, mún nā kèìn nèe tsūūu jà jē since 1SG born.PFV 1SG NEG bird DEM like see yet 'Since I was born, I have never seen a bird like that (yet).' (Solomiac 2007:250)

(4) tò y’á tàrà wó nō kéré pyē wāā DEM SBJV.3SG find 2SG NEG born yet NEG

'[The old man should tell you that there has been this intelligence like this], while you were not yet born.' (Solomiac 2007:252) 
Bena-Yungur

(5) áyà

kōp mbú kófā kālkāl

3SG.AN.COP.at eating thing eaten still

'He is still eating (food)'.

(6) a sóm á kōp mbú kófā rē kálkāl

3SG.AN COP.NEG at eating thing eaten NEG yet

'He is not eating (food) yet'.

Given that CFNMs tend to occupy the same constructional slot as phasal polarity expressions (PPEs) in Sub-Saharan African languages and that strong semantic and often also formal links are known to exist between PPEs and negation (cf. various semantic and typological accounts of PPEs, such as Löbner 1989; van der Auwera 1993; van der Auwera 1998; van Baar 1997), CFNMs may be expected to often develop out of PPEs. Yet, this expectation is not borne out by the data available on the development of CFNMs in the languages of NSSA (cf. Idiatov 2012a; 2012b; 2015; Devos \& van der Auwera 2013). In fact, it seems to be a more broad cross-linguistic generalization that PPEs rarely develop into default negation markers. Thus, in some cases of a Jespersen cycle type of emergence of negation markers (cf. van der Auwera 2009), PPEs are known to have been competing for the status of the new default negation marker and to have lost this competition to expressions of other semantics. For instance, in the history of French it was the minimizer pas '(not) a step' which has become generalized as the default negation marker rather than a PPE such as plus '(not) anymore'.

This paper discusses a number of cases from Mande languages where CFNMs may be argued to be historically related to PPEs. In line with the general rarity of the change from PPEs to default CFNMs, when evolving into negation markers PPEs tend to maintain the phasal element of their semantics or become restricted to certain TAM constructions (Section 2). In the rare cases where PPEs may be argued to have evolved into default CFNMs, this evolution is not direct and necessarily proceeds through the addition and foregrounding of a free-choice indefinite semantic component (such as 'not yet' > 'not ever yet, not on any occasion yet') and the development of the implicature of an intersubjective operator processing hearer-sided expectations and presuppositions (such as 'not ever yet, not on any occasion yet' > 'not at all, really not') (Section 3). Finally, I highlight the fact that we need to pay careful attention to the source semantics of the element that has both PPEs and default CFNMs as reflexes, as the PPE uses may not be the source of the CFNM uses (Section 3). 


\section{The historical relation between PPEs and non-default CFNMs}

In this section, I illustrate that in their evolution to negation markers, PPEs tend to maintain the phasal element of their semantics, such as the non-default CFNM $\eta \bar{e}$ '(not) yet' in Dzuun [dnn] (2.1) or the emergent negative polarity item bilen 'anymore' in Bamana [bam] (2.2), or become restricted to certain TAM constructions, such as the Negative Perfect CFNM bé 'not yet' in Tura [neb] (2.3). I particularly highlight the intricate historical relations between the phasal polarity and negation uses of these markers.

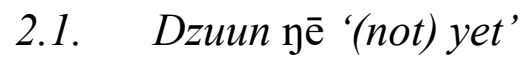

As I discuss in more detail in (Idiatov 2015; 2018:125-127), Dzuun [dnn], a Western Mande language spoken in Burkina Faso and described by Solomiac (2007), has a default CFNM wāa, as in (7), which may be omitted under certain conditions. In addition, Dzuun has a number of CFNMs that are semantically narrower than the default CFNM wāa $\bar{a}$, such as $d \bar{\varepsilon}$ 'anymore, no more', kürāa ' '(n)ever; (not) at all' and $\eta \bar{e}$ '(not) yet'. In fact, some of the forms that function as non-default CFNM markers can also occur in positive constructions, as the clause-final PPE $\eta \bar{e}$ 'yet, still' in (2). Although semantically specific CFNMs, such as $\eta \bar{e}$, can be combined with the default CFNM wāa, as in (4), in which case $\eta \bar{e}$ functions as a PPE rather than a CFNM, usually semantically specific CFNMs replace the default CFNM $w \bar{a} \bar{a}$, as in (3). It is precisely the fact that $\eta \bar{e}$ occupies the CFNM slot of the default CFNM wāa that makes us analyze it in (3) as a semantically specific CFNM rather than a PPE. From a theoretical perspective, semantically specific CFNMs, such as Dzuun $\eta \bar{e}$, are particularly interesting for two reasons. First, they illustrate a possibility that a marker need not be a dedicated negation marker (be intrinsically negative in its meaning) to be a CFNM. Second, they showcase that a particular way of expressing negation within a negation construction, such as the clause-final negation marking, may be obligatory while the negation markers themselves may be optional to various degrees (since all CFNMs can replace each other, albeit sometimes with a change in propositional meaning). The situation in Dzuun is a somewhat more complicated version of what one finds in French, where the new default (post-verbal) negation marker pas can be replaced by a number of more specific negation markers, such as jamais '(n)ever' or nulle part 'nowhere', some of which can also be used in positive constructions, such as si jamais 'if ever' and pour jamais 'forever'. 
Dzuun

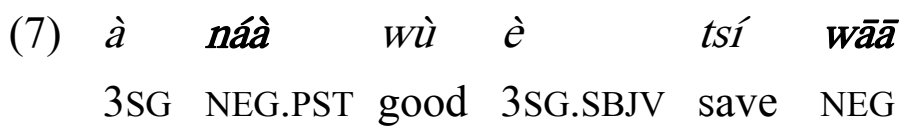

'It was not good that he be saved.' (Solomiac 2007:270)

\subsection{Bamana bilen 'anymore'}

The marker bilen (bèlen, bile) in Bamana [bam], a Western Mande language spoken in Mali without a default CFNM, can be used in a number of constructions, where it functions as a PPE 'anymore', repetition marker 'again', discourse marker 'though, yet, however, but', interjection 'still?!, now?! (with a nuance of surprise and reproach)' or a negative conditional clause marker (cf. Bailleul 1996; Dumestre 1990; 2003:311; Vydrin \& Tomchina 1999). ${ }^{4}$ The last three uses (discourse marker, interjection and negative conditional marker) are marginal. The most common usage of bilen is in negative clauses as a clause-final PPE with the meaning 'not anymore, no longer', as in (8). The negation is expressed by the negative TAM auxiliary or copula in the immediately post-subject slot.

Bamana

(8) né

$$
\text { té fâama yé bìlen }
$$

1SG.EMPH COP.NEG king.ART as anymore

'I am not the king anymore.' (Dumestre 2003:311)

Although in verbal clauses with non-present semantics, such as (9) and (10), bilen may also sometimes be interpreted as the negation of 'again', it is not a repetition marker, as explicitly stated by Dumestre (2003:311) who decomposes the meaning of bilen in such examples as 'from this point forward' (French desormais) plus negation. 5

Bamana

(9) é

té dénmiscn bùgo bilen

2SG.EMPH IPFV.NEG child.ART beat anymore

'You will not beat the children anymore.' (Dumestre 2003:311)

\footnotetext{
${ }^{4}$ All these uses are historically related and ultimately go back to the verb which has also resulted in the Bamana verb bàli '(vt) prevent, stop (from doing something); (vi) fail, not succeed (with something, in doing something)'. Both bilen and bàli are reflexes of the Intransitive form of the Proto Mande verb *Gàdáy 'bump into, stumble into, unexpectedly come across an obstacle'. A discussion of the details of the reconstruction goes beyond the scope of this paper.

${ }^{5}$ Presumably, because similarly to the French non-default negation marker plus, it should not be possible to use it in contexts like 'Today, the bus did not come on time again'.
} 
(10) à má nà bìlen

3SG PFV.NEG come anymore

'He did not come anymore.' (Bailleul 1996)

The free-choice indefinite component inherently present in the semantics of the negative clause-final PPE bilen 'not anymore' may sometimes become foregrounded at the expense of the phasal polarity component, viz. 'not (on any occasion) from the reference point forward' > 'not on any occasion, not at all (from the reference point forward)' $>$ 'not on any occasion, not at all', as in (11).

Bamana

(11) ù má sòn kà dòn sánsara kóno bìlen

3PL PFV.NEG agree INF enter cage.ART in on.any.occasion

'They did not agree to enter the cage on any occasion.' (Vydrin \& Tomchina 1999)

Like Dzuun $\eta \bar{e}(2.1)$, bilen can also be occasionally used in positive clauses, as in (12), where it has the meaning 'again'. In this rare positive use, bilen can not only be used in the clause-final slot, like its negative counterpart, but also in the operator slot immediately after the subject and before the TAM and polarity auxiliary, as in (13), or before the verb in predicative constructions without an auxiliary, as in (14). This operator slot also hosts bilen in its use as a discourse marker and as a negative conditional marker. Finally, as a negative conditional marker bilen can also itself occupy the TAM and polarity auxiliary slot.

Bamana

(12) í bé yàn bìlen!

2SG COP here again

'You are again here!' (Vydrin \& Tomchina 1999)

(13) kònoba bìlen $y^{\prime a ̀ ~} \quad$ fó...

big.bird.ART again PFV.TR $=3$ SG say

'The big bird said again...' (Dumestre 2003:311)

(14) à bìlen bòli-la kà n’à fó à bámuso yé

$3 \mathrm{SG}$ again run-PFV.IT INF come $=3 \mathrm{SG}$ say $3 \mathrm{SG}$ mother.ART to

'She ran again to tell her mother about it.' (Vydrin \& Tomchina 1999)

As a clause-final PPE, bilen 'anymore' can be characterized as an emergent negative polarity item, since the clause needs to be negative for bilen to have its PPE meaning 'anymore' and bilen has a different meaning, 'again', when it is used in the 
same clause-final position in a positive clause. Moreover, bilen as 'again' in positive clauses can equally occupy a different slot in the clause structure, viz. the post-subject operator slot. From a Mande comparative perspective, the emergence of such a negative polarity item is noteworthy, since generally Mande languages have only few negative polarity items, such as the Bamana determiner si 'none' and the clause-final marker féwú 'absolutely not, no way'. Another interesting point with respect to the clause-final PPE bilen as an emergent negative polarity item is that it illustrates how the foregrounding of the free-choice indefinite semantic component of a PPE may lead to the development of the implicature of an intersubjective operator, such as 'not at all (contrary to what you may have expected)'. This kind of semantic evolution may eventually result into a CFNM. Thus, in a number of Southeastern Bamana dialects that have default CFNMs, these markers have evolved through a similar semantic change from a frequency adverbial 'once, at one time, at a certain moment' (cf. Idiatov 2012b).

\subsection{Tura bé 'not yet'}

Tura [neb], a Southeastern Mande language spoken in Côte d'Ivoire and described by Bearth (1971), does not have a default CFNM but it has a non-default CFNM bé that is part of the Negative Perfect construction, as in (15-17).

Tura

(15) é

$$
\text { lốó wó-ó, òó nû́ } \quad \text { bé }
$$

3SG.CONJ go $=$ FOC do $\backslash$ PFV-PFV 3SG.PFV.NEG come yet

'Since he left, he has not come back.' (Bearth 1971:283)

(16) é

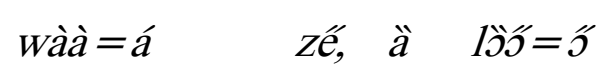

òó

$m$ m气̂̃ bé

3SG.CONJ arrive $\backslash$ PFV-PFV here 3SG duration $=$ FOC 3SG.PFV.NEG last yet

'Since he arrived here, not much time has passed.'

(17) $\boldsymbol{m}$ 苂

$$
\text { à yé dó bé }
$$

1SG.PFV.NEG 3 SG see once yet

'I have never seen him.' (lit.: 'I have not seen him once')

Although bé can be glossed as 'not yet', I do not use 'yet' in the translation because bé is obligatory in the Negative Perfect construction. The presence of the CFNM bé is the only thing that distinguishes the Negative Perfect construction from the Negative Perfective construction, as in (18) that can be compared to (17). 
Tura

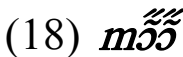

à yé

1SG.PFV.NEG 3SG see

'I did not see him.' (e.g., as an answer to the question 'Did you see him at the market?') (Negative Perfective)

Therefore, one might also wish to say that bé is a PPE and at the same time a negative polarity item restricted to the Negative Perfective construction, where its presence just implies the negative perfect meaning. However, I prefer the analysis of bé as a CFNM of a dedicated Negative Perfect construction because in the positive polarity, the Perfect and the Perfective constructions are clearly two different constructions. Thus, the Positive Perfect construction, as in (19), differs from the Positive Perfective construction, as in (20), by the TAM auxiliary used (fused with pronominal subject indexes) and the absence of additional TAM marking on the verb itself.

Tura

(19) $\eta \dot{\eta} \quad n \tilde{\varepsilon}=\tilde{\tilde{\varepsilon}} \quad$ lô bòr

$1 \mathrm{SG}$ father $=$ PRF go in.the.field

'My father has gone to the field.' (Positive Perfect)

(20)

1SG father COP go\PFV-PFV in.the.field

'My father went to the field.' (Positive Perfective)

Outside of the Negative Perfect construction, bé is used as an adverbial with existential semantics, usually with the copula or the verb tö 'be(come)', as in (21-23).

Tura

(21) póné ké Gé

something COP EXIST

'There is something.' (Bearth 1971:205)

(22) póné àá Gé

something 3SG.COP.NEG EXIST

'There is nothing.' (Bearth 1971:205)

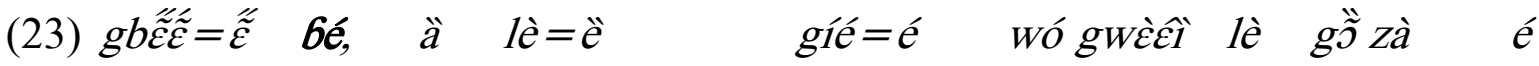
$\operatorname{dog}=$ COP EXIST 3 SG FOC $=$ IPFV.FOC pass $=$ FOC do baboon FOC at though this 'Here you are, it's the dog though who wins over the baboon.' (lit.: 'There is the dog, it is it who wins over the baboon, though, here you are.') (Bearth 1971:381) 
This strongly suggests that, originally, be is not a PPE, but some kind of deictic adverbial. That is, bé did not become confined to the Negative Perfective construction as a PPE with this combination being later conventionalized as the Negative Perfect construction. What is more likely to have happened is that bé first developed its phasal polarity semantics when used in the Negative Perfective construction with the verb tö 'be(come)', then its phasal polarity use became available for other verbs in the Negative Perfective construction and only after that the combination of bé and the Negative Perfective became conventionalized as the negative counterpart of the Positive Perfect construction.

\section{The historical relation between PPEs and default CFNMs: intersubjective implicatures as the middleman and the importance of the source meanings}

In this section, I consider the two Mande examples where earlier PPEs can be argued to have resulted in default CFNMs. Both examples come from Bobo and Samogo languages, two distantly related Western Mande groups spoken in the same general area in the west of Burkina Faso and the bordering regions of southeastern Mali. The first example (Section 3.1) is represented by the reflexes of the etymon *kè in a number of Samogo languages, viz. the CFNMs of the Samogo languages Jo [jow] kì, Seen [sos] gè and presumably the Kpeen [cpo] nè or nì. The same etymon *kè also resulted in the Dzuun non-default CFNM and PPE $\eta \bar{e}$ 'yet, still' already discussed in Section 2.1 (also see examples 2-4 in Section 1). The second example (Section 3.2) comprises a number of reflexes of the etymon *kútà-Cá, ${ }^{6}$ viz. the default CFNMs of Northern Bobo [bbo] $k \bar{s}$, Sya Southern Bobo [bwq] gā $\sim g a ́$, the optional CFNM kpá of Benge Southern Bobo [bwq], the default CFNMs of the Samogo languages Dzuun [dnn] wāa, Ban [bxw] $m \bar{a}$ and Kpaan [dnn] $\tilde{u} \sim \tilde{W}$, and the Dzuun non-default CFNM kūrāā '(n)ever; (not) at all'. I discuss both cases in more detail in (Idiatov 2015), where I focus on the formal reconstruction of the two etymons and where I particularly highlight the complex history of parallel evolution and borrowing of these CFNMs in Bobo and Samogo languages. Here, I will focus on the details of their semantic evolution, in particular on the details of the historical relations between their uses as PPEs and their uses as CFNMs. The main generalization is that the evolution from a PPE to a default CFNM has proceeded through the addition and foregrounding of a free-choice indefinite semantic component. Furthermore, in the case of * $k e ̀$ its original meaning as an indefinite determiner 'some,

\footnotetext{
${ }^{6}$ In Idiatov (2015), I reconstruct this etymon as *kÚDà(C)á. The revised reconstruction *kútà-Cá presented here does away with the underspecified first vowel and second consonant, introduces a morpheme boundary before the final syllable and confirms the presence of the third consonant, whose identity remains unknown.
} 
a certain' suggests that it its evolution into a default CFNM need not have proceeded through a PPE stage.

\subsection{Reflexes of *kè}

The default CFNMs of the Samogo languages Jo [jow] kì, Seen [sos] pè and presumably Kpeen [cpo] nè or nì are all related to the Dzuun non-default CFNM and PPE $\eta \bar{e}$ 'yet, still'. Example (3), reproduced here as (24), shows how a CFNM meaning 'yet' may acquire an additional overtone of universal quantification, as 'ever yet', 'never (yet)'.

\section{Dzuun}

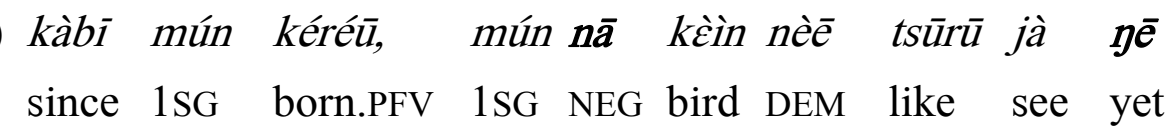

'Since I was born, I have never seen a bird like that.' (lit.: 'Since I was born, I have not seen a bird like that yet.') (Solomiac 2007:250)

Example (24) contrasts with the Tura example (17) where the adverb dó 'once' (meaning 'not once' under negation) is used to add the same universal quantification meaning. From here, the temporal directionality inherent to the meaning 'yet, still' of $\eta \bar{e}$ may weaken, especially if the marker becomes confined to negative predications, to come to mean plainly 'never'. A further foregrounding of the free-choice indefinite component present in the semantics of 'never (yet)' at the expense of its temporal semantics to something like '(not) at all' is easy to conceive, viz. 'not (on any occasion) before the reference point' $>$ 'not on any occasion, not at all (before the reference point)' $>$ 'not on any occasion, not at all'. In this respect, recall the possibility of a similar foregrounding of the free-choice indefinite component in the semantics of the Bamana negative clausefinal PPE bilen 'not anymore' in (11). Also compare several other Dzuun non-default CFNMs, such as fyēū '(n)ever; (not) at all' and kūrāā '(n)ever; (not) at all', that can equally express both meanings. In addition to the restriction of the marker in question to negative predications, this addition of a free-choice indefinite semantic component as a possible implicature and later foregrounding and conventionalization of the latter at the expense of the phasal polarity component are necessary steps for the evolution of this marker into a default CFNM.

Comparative Mande data show that the original meaning of the etymon *kè is an indefinite determiner 'some, a certain, any'. Thus, among its cognates across Mande we find the Tura [neb] determiner ké 'a certain, some; a little; another; again', ${ }^{7}$ its adverbial

\footnotetext{
${ }^{7}$ This determiner may have the meaning 'again' when it modifies a nominalized verb in a construction with a light verb wó 'do', viz. something like 'do another going' meaning 'go again'. In the same construction, this determiner may also has its indefinite quantifying meaning, viz. something like 'do some, a bit of going' meaning 'go a bit'.
} 
derivate ké-wó 'again; (not) anymore', the Gban [ggu] determiner ké 'another, again', the Bokobaru [bus] determiner $k \bar{e}$ 'a certain; any; none, (not) any'. The semantic evolution starting with 'a certain, some' proceeding through 'another' to, as a verbal modifier, 'again', and subsequently to a PPE 'still' is not particularly striking. No more striking is the subsequent shift within the domain of PPEs from 'still' to 'not yet', through the mechanism of "internal negation" (viz. 'still (not P)' = 'not yet P'), and from 'still' to 'not anymore', through the mechanism of "external negation" (viz. 'not (still P)' = 'not anymore P') (cf. the Duality Hypothesis of Löbner 1989 describing the semantic relations between various PPEs in terms of internal and external negation). However, the origin of *kè in an indefinite determiner 'some, a certain, any' also makes conceivable another path towards a default CFNM through a minimizer and without passing through the stage of a PPE, viz. 'some, a certain' > 'a bit, a little' > '(not) a bit' $>$ '(not) at all'. Both paths are equally plausible. Thus, the history of * $k e$ highlights the fact that we need to pay careful attention to the source semantics of the element that has both PPEs and default CFNMs as reflexes, as the PPE uses may not be the source of the CFNM uses.

\subsection{Reflexes of *kútà-Cá}

The default CFNMs of Northern Bobo [bbo] ks, Sya Southern Bobo [bwq] $g \bar{a} \sim g a ́$, the optional CFNM kpá of Benge Southern Bobo [bwq], the default CFNMs of the Samogo languages Dzuun [dnn] wāa, Ban [bxw] $m \bar{a}$ and Kpaan [dnn] $\tilde{u} \sim \tilde{w}$, and the Dzuun [dnn] non-default CFNM kürāāa '(n)ever; (not) at all' can all be argued to be reflexes of the etymon *kútà-Cá. As I argue in (Idiatov 2015), the Dzuun non-default CFNM kūrāā '(n)ever; (not) at all' is the direct reflex of *kútà-Cá, while the default CFNMs of Dzuun, Kpaan and Ban are only indirect reflexes resulting from a lateral transfer of the Bobo CFNM, which expanded an already rich system of semantically more specific CFNMs in these Samogo languages. The initial part *kútà is originally a modifier 'new, next, recent', in its adverbial use meaning 'anew, again'. Thus, among its cognates across Mande we find the Bamana adjective kúrá 'new, next, recent' (corresponding to Mandinka [mnk] kútá), also as part of the adverb kó-kúrá 'again' (lit. 'matter new'), the Bamana expressive adverb kúdáyi 'forever; definitely; (not) forever, never again', Susu [sus] kj̀ré 'henceforth, from now/then on; (not) anymore, never', and the Tige Bozo [boz] adverb or operator xua 'again; (not) again; (not) anymore'. The final part *-Cà must be an adverbial marker, most likely sourced from a postposition or a light verb. ${ }^{8}$

\footnotetext{
${ }^{8}$ Thus, compare Tura ké-wó 'again; (not) anymore', the adverbial derivate of the determiner ké 'a certain, some; a little; another; again' mentioned in Section 3.1, where the adverbial marker goes back to the light verb wó '(vt) do; (vi) happen'.
} 
Given the original meaning 'new, next, recent', we can be much more sure than in the case of *ke discussed in 3.1 that the semantic evolution of this etymon to a default CFNM has proceeded through a PPE stage. However, like in the case of the PPEscenario for the evolution of * $k e$ into a default CFNM, the PPE stage in the evolution of *kútà-Cá towards a default CFNM must also have proceeded through the addition of a free-choice indefinite semantic component as a possible implicature and later foregrounding and conventionalization of the latter at the expense of the phasal polarity component. This later evolution is exemplified by the Dzuun non-default CFNM kürāa '(n)ever; (not) at all'. The proposed semantic development of *kútà-Cá can be summarized as follows (focusing on the use of this marker in negative predications): 'new, recent, next' > 'anew, again' > 'again; still' > (through the mechanism of "external negation" of 'still') '(not) anymore' > 'not (on any occasion) from the reference point forward' > 'not on any occasion, not at all (from the reference point forward)' $>$ 'not on any occasion, not at all' $>$ CFNM.

\section{Conclusions}

Although in Sub-Saharan African languages CFNMs tend to occupy the same constructional slot as PPEs and strong semantic and often also formal links are known to exist between PPEs and negation, PPEs rarely develop into default CFNMs. As I have argued on the example of a number of Mande languages, in those rare cases when PPEs do develop into default CFNMs, this evolution necessarily proceeds through a number of intermediate steps (Section 3). It begins with the addition of a free-choice indefinite semantic component as a possible implicature. This implicature is later foregrounded and conventionalized at the expense of the phasal polarity component. For instance, a PPE such as 'not yet, not before the reference point' by preference used in negative predications may be added a free-choice indefinite semantic component as a possible implicature to mean 'not (on any occasion) before the reference point' (i.e. 'never yet'). This implicature may later be foregrounded at the expense of the phasal polarity component resulting in 'not on any occasion, not at all (before the reference point)' and finally conventionalized as 'not on any occasion, not at all' with the loss of the phasal polarity component. On this last stage before being conventionalized as a default CFNM, i.e. when these markers are generally glossed as 'not at all', they effectively become integrated in the paradigm of clause-final intersubjective operators processing hearer-sided expectations and presuppositions ("monitoring-and-directing operators" in terms of Matras 2009:99), particularly common in the languages of Sub-Saharan Africa, especially in its northern part. Most commonly, this integration is manifested by the competition for the clause-final slot between CFNMs and various other intersubjective operators, as briefly illustrated in Section 1 (see also Idiatov 2015:242-245 for an 
illustration of some less trivial manifestations of this integration in Dzuun). Finally, I draw attention to the fact that when considering an apparent relationship between a PPE and a default CFNM in a given language, we need to pay careful attention to the source semantics of the element that has both PPEs and default CFNMs as reflexes, as the PPE uses may not be the source of the CFNM uses (Section 3.1).

Another type of historical relations between PPEs and CFNMs that I illustrated in the paper with the help of Mande data is the possibility of an evolution of PPEs into non-default CFNMs (Section 2). The historical relations between the phasal polarity and negation uses of a given marker can be rather intricate, but the main generalization is that when evolving into negation markers PPEs tend to maintain the phasal element of their semantics or become restricted to certain TAM constructions.

\section{Glosses:}

$\begin{array}{llll}\text { AN } & \text { animate } & \text { NEG } & \text { negation } \\ \text { ART } & \text { article } & \text { PFV } & \text { perfective } \\ \text { CFNM } & \text { clause-final negation marker } & \text { POSS } & \text { possessive } \\ \text { COP } & \text { copula } & \text { PPE } & \text { phasal polarity expression } \\ \text { CONJ } & \text { conjoined } & \text { PRF } & \text { perfect } \\ \text { DEM } & \text { demonstrative } & \text { PST } & \text { past } \\ \text { EMPH } & \text { emphatic } & \text { REFL } & \text { reflexive } \\ \text { EXIST } & \text { existential } & \text { REL } & \text { relative } \\ \text { FOC } & \text { focus } & \text { SG } & \text { singular } \\ \text { INF } & \text { infinitive } & \text { SBJV } & \text { subjunctive } \\ \text { IPFV } & \text { imperfective } & \text { TAM } & \text { tense-aspect-modality } \\ \text { IT } & \text { intransitive } & \text { TR } & \text { transitive }\end{array}$

\section{References:}

Bailleul, Charles. 1996. Dictionnaire bambara-français. Bamako: Éditions Donniya. Bearth, Thomas. 1971. L'énoncé toura (Côte d'Ivoire). Norman: Summer Institute of Linguistics, University of Oklahoma.

Beyer, Klaus. 2009. Double negation marking: A case of contact-induced grammaticalization in West-Africa? In Norbert Cyffer, Erwin Ebermann \& Georg Ziegelmeyer (eds.), Negation patterns in West African languages and beyond, 205-222. Amsterdam: John Benjamins.

Devos, Maud \& Johan van der Auwera. 2013. Jespersen Cycles in Bantu: double and triple negation. Journal of African Languages and Linguistics 34(2). 205-274.

Dryer, Matthew S. 2009. Negation patterns in West African languages and beyond. In Norbert Cyffer, Erwin Ebermann \& Georg Ziegelmeyer (eds.), Verb-objectnegative order in Central Africa, 307-362. Amsterdam: John Benjamins. 
Dumestre, Gérard. 1990. Notes sur le morphème de l'hypothétique bilen en bambara. Mandenkan 20. 41-46.

Dumestre, Gérard. 2003. Grammaire fondamentale du bambara. Paris: Karthala.

Idiatov, Dmitry. 2012a. On the history of clause-final negation in the Mande languages of the Bani - upper Mouhoun rivers area. Paper presented at the Workshop "The history of post-verbal negation in African languages" (7th World Congress of African Linguistics). URL: http://idiatov.mardi.myds.me/WOCAL7_Negation/IDIATOV_2012_Presentati on.pdf.

Idiatov, Dmitry. 2012b. Clause-final negative markers in southeastern Bamana dialects: a contact-induced evolution. Africana Linguistica 18. 169-192.

Idiatov, Dmitry. 2015. Clause-final negative markers in Bobo and Samogo: parallel evolution and contact. Journal of Historical Linguistics 5(2). 235-266. DOI: 10.1075/jhl.5.2.02idi.

Idiatov, Dmitry. 2018. An areal typology of clause-final negation in Africa: language dynamics in space and time. In Daniël Van Olmen, Tanja Mortelmans \& Frank Brisard (eds.), Aspects of linguistic variation, 115-163. Berlin: De Gruyter Mouton. DOI: 10.1515/9783110607963-005.

Löbner, Sebastian. 1989. German schon - erst - noch: An integrated analysis. Linguistics and Philosophy 12(2). 167-212. DOI: 10.1007/BF00627659.

Matras, Yaron. 2009. Language contact. Cambridge: Cambridge University Press.

Roulon-Doko, Paulette. 2012. Le marqueur de négation ná en gbaya. Paper presented at the Workshop "The history of post-verbal negation in African languages" (7th World Congress of African Linguistics), Buea. URL: http://idiatov.mardi.myds.me/WOCAL7_Negation/ROULON-

DOKO_2012_Presentation.pdf.

Solomiac, Paul. 2007. Phonologie et morphosyntaxe du dzùùngoo de Samogohiri. Lyon: Université Lumière Lyon $2 \mathrm{PhD}$ thesis.

van Baar, Tim. 1997. Phasal polarity. Amsterdam: IFOTT.

van der Auwera, Johan. 1993. "Already" and "Still": Beyond Duality. Linguistics and Philosophy 16(6). 613-653. DOI: 10.1007/BF00985436.

van der Auwera, Johan. 1998. Phasal adverbials in the languages of Europe. In Johan van der Auwera \& Dónall P.O. Baoill (eds.), Adverbial constructions in the languages of Europe, 25-145. Berlin, New York: Mouton de Gruyter.

van der Auwera, Johan. 2009. The Jespersen cycles. In Elly van Gelderen (ed.), Cyclical change, 35-71. Amsterdam: John Benjamins. 
Vydrin, Valentin \& Svetlana Tomchina. 1999. Manding-English dictionary (Maninka, Bamana). Vol. 1 (A, B, D-DAD, supplemented by some entries from subsequent volumes). St. Petersburg: Bulanin. 